\title{
Global query on bacterial sirtuin CobB interactants reveals crosstalk with PRPP synthase Prs
}

3

4

5

6

7

8

9

10

11

Beata M. Walter ${ }^{1}$, Joanna Morcinek-Orłowska ${ }^{1}$, Aneta Szulc ${ }^{1}$, Andrew L. Lovering ${ }^{2}$, Manuel Banzhaf $^{2}$, Monika Glinkowska ${ }^{1} \square$

1- Department of Bacterial Molecular Genetics, Faculty of Biology, University of Gdansk, Gdansk, Poland

2 - Institute of Microbiology \& Infection and School of Biosciences, University of Birmingham, UK;

$\square$ - to whom correspondence should be addressed; monika.glinkowska@ug.edu.pl 


\section{Abstract}

Protein lysine acetylation regulates a wide range of cellular functions. It is controlled by a family of NAD-dependent protein deacetylases called sirtuins. In eukaryotes, sirtuins activity is coupled to spatiotemporally-controlled NAD+ level, whereas the mechanism of their regulation in bacteria is less clear. E. coli possesses a single sirtuin - CobB. However, it is unclear how CobB activity is coupled to NAD+ metabolism. In this work we show that this coordination is achieved in E. coli cells through a CobB interaction with PRPP synthase Prs, an enzyme necessary for NAD+ synthesis. Employing global analysis of protein-protein interactions formed by CobB, we demonstrate that it forms a stable complex with Prs. This assembly stimulates CobB deacetylase activity and partially protects it from inhibition by nicotinamide. We provide evidence that Prs acetylation is not necessary for CobB binding but affects the global acetylome in vivo. Our results show that CobB ameliorates Prs activity under conditions of Prs cofactors deficiency. Therefore, we propose that CobB-Prs crosstalk orchestrates the NAD+ metabolism and protein acetylation in response to environmental cues.

Key words: Protein acetylation/ sirtuins/ NAD metabolism/ phosporibosyl pyrophosphate

\section{Intoduction}

Lysine acetylation is a post-translational protein modification regulating a wide range of protein functions. It has been investigated thoroughly in eukaryotic cells and recently was discovered to be important for protein regulation in prokaryotes as well (Christensen et al, 2019; Bernal et al, 2014). In bacteria, the level of protein acetylation is a result of two counterbalancing processes. On one hand, proteins become acetylated enzymatically or chemically, by lysine transacetylases or acetyl phosphate, respectively (Ma \& Wood, 2011; Weinert et al, 2013; Kuhn et al, 2014). In the opposing process, acetyl groups are removed from acetyl-lysine residues by deacetylases, most of which are NAD+-dependent homologs of eukaryotic sirtuins (Greiss \& Gartner, 2009; Imai \& Guarente, 2010).

CobB is a highly conserved protein lysine deacetylase among bacteria (Landry et al, 2000; Tsang \& Escalante-Semerena, 1998). It removes the acetyl group from acetyl-lysines, utilizing NAD+ and producing nicotinamide (NAM) and 2"-O-acetyl-ADP-ribose as byproducts. CobB is also the only sirtuin-like deacetylase identified in E. coli so far (Zhao et al, 2004). Its activity regulates global protein acetylation level (Choudhary et al, 2014; Castaño-Cerezo et al, 2014; Weinert et al, 2017, 2013; Kuhn et al, 2014) and thus affects many cellular functions, including gene expression (Thao et al, 2010; Lima et al, 2011; Qin et al, 2016), the cell cycle (Zhang et al, 2016), metabolism (Castaño-Cerezo et al, 2011; Venkat et al, 2017; Castaño-Cerezo et al, 2014), stress response ${ }^{3,12}$, motility and pathogenicity (Liu et al, 2018). In addition, CobB can also act as desuccinylase, de-2-hydroxyisobutyrylase and lipoamidase (Colak et al, 2013; Dong et al, 2019; Rowland et al, 2017). Despite its important role, factors affecting protein deacetylation rate in bacteria are poorly understood. The levels of CobB reaction product NAM (Gallego-Jara et al, 2017), as well as NADH and c-di-GMP (Xu et al) have been implicated in regulation of CobB activity so far.

In eukaryotic cells, interplay between activity of sirtuins and NAD + metabolism is well established, showing that NAD+ is a crucial factor in controlling chromatin structure, DNA repair, lifespan and circadian rhythm (Imai \& Guarente, 2016; James Theoga Raj \& Lin, 2019). This makes NAD+ not only an enzyme cofactor in various redox reactions but also an important signaling molecule. Bacterial sirtuins on the other hand, have low $\mathrm{K}_{\mathrm{m}}$ 's for NAD+ 
whereas its intracellular concentration is high (Guan et al, 2014). This may jointly result in lower sensitivity of bacterial sirtuins to regulation by NAD+ than their eukaryotic homologues. In vivo, the level of $\mathrm{NAD}+$ is maintained by de novo synthesis and salvage pathways (Fig. 1). Both pathways require the pivotal metabolite phosphoribosyl pyrophosphate (PRPP) that is produced by the evolutionary conserved PRPP synthase - Prs (Gazzaniga et al, 2009).

In this work we propose that coordination between NAD+ metabolism and protein acetylation is exerted in E.coli by crosstalk of the CobB deacetylase with the PRPP synthase Prs. Namely, we provide evidence that CobB forms a stable complex with Prs affecting its deacetylase activity. Formation of this complex is not dependent on Prs acetylation status in vitro but modification of Prs by lysine acetylation affects CobB function in vivo. We also show that, under certain conditions, the rate of PRPP synthesis by Prs may be influenced by CobB. Based on those observations, we propose a model how this mutual dependence links NAD+ metabolism and cellular energetics to protein acetylation.

\section{Results}

CobB interacts with phosphoribosyl phosphate synthase in vivo and in vitro. Numerous acetylated proteins have been suggested to be CobB targets in vivo. Some of them were found in global acetylome studies showing differential acetylation of proteins in wild-type and $\triangle \operatorname{cobB}$ mutants (Castaño-Cerezo et al, 2014; Weinert et al, 2017). Others were identified as CobB interactants with the use of a protein microarray consisting of the majority of the $E$. coli proteome ( $\sim 4000$ protein, non-acetylated) (Liu et al, 2014). In order to investigate the regulation of CobB-mediated protein deacetylation we first aimed to identify its interaction partners under physiologically relevant conditions. For this, we performed an immunoprecipitation pull-down, dubbed sequential peptide affinity purification (SPA)(Babu et al, 2009). In this approach, proteins are labeled with a double-affinity tag consisting of triple FLAG epitope and calmodulin binding protein (CBP), separated by a protease cleavage site. After immunoprecipitation from cell lysates with anti-FLAG antibodies, protein complexes are released from the resin by protease digest and re-purified using a calmodulin sepharose column. As a bait, we used chromosomally expressed (from the native promoter), C-terminally SPA-tagged CobB. Subsequently to the pull-down, interaction partners were identified by liquid chromatography coupled to tandem mass spectrometry (LC-MS/MS). The experiments have been carried out using cells grown to stationary phase in a rich undefined medium (LB) and minimal medium containing acetate as a carbon source, both conditions supporting high protein acetylation level. Under those conditions, the major component of the

purified CobB complex was the phosphoribosyl phosphate synthase Prs (Supplementary Table 1). This interaction has been previously described by others in a large-scale study of protein-protein interactions, confirming validity of our results (Butland et al, 2005). We further compared our data with the interactions previously described in a CobB protein microarray study (Liu et al, 2014). We found the fatty acids synthesis proteins FabB and FabG are significantly enriched in the presence of CobB, in comparison to control samples analyzed by LC-MS/MS. However, other interactants found in this microarray study were not present or enriched in our data set, suggesting that those interactions are of lower affinity or more transient than the one between CobB and Prs (Supplementary Table 1).

We further confirmed the Prs and CobB interaction performing the pull-down experiment in a reversed set-up, where SPA-tagged Prs was used as a bait (Supplementary Table 1). 
bioRxiv preprint doi: https://doi.org/10.1101/2020.12.09.417477; this version posted December 9,2020 . The copyright holder for this preprint (which was not certified by peer review) is the author/funder, who has granted bioRxiv a license to display the preprint in perpetuity. It is made available under aCC-BY-NC-ND 4.0 International license.

Consistently, we observed binding of purified His-tagged Prs (bait) and CobB (prey) in a pulldown experiment (Fig. 2A).

Overall, these results indicate that CobB forms a stable complex with Prs in E. coli.

CobB-Prs interaction is not affected by the Prs acetylation state. Prs has been previously reported as one of the proteins acetylated in vivo at widely-conserved positions K182, K194, K231(Kuhn et al, 2014; Castaño-Cerezo et al, 2014; Weinert et al, 2017) (Supplementary Fig. 1). Therefore, we investigated whether Prs interaction with the CobB is affected by acetylation of its lysine residues. To achieve this, we repeated the pull-down experiment using acetylated His-tagged Prs and CobB. Prs was acetylated in vitro by reacting with acetyl phosphate, as described before by others (Kuhn et al, 2014; Qin et al, 2016). Subsequently, successful

modification of lysine residues was confirmed by western blot (Fig. 2B). In addition, we verified by mass spectrometry that acetylated Prs lysine residues are mainly those previously shown to become modified this way in vivo (K182, K194, K231)(Table 1). Chemically acetylated Prs interacted with CobB in a manner indistinguishable from the unmodified protein (Fig. 2C). It is worth noting that the pull-down reactions did not contain NAD+, disabling deacetylation of Prs by CobB during the course of reaction. Next, we confirmed that Prs becomes deacetylated by CobB in vitro (Fig. 2D, Table 1). Our experiments revealed also that CobB likewise becomes acetylated by acetyl phosphate in a system consisting of purified proteins (Fig. 2B) and acetylation has a moderate influence on its deacetylase activity (Fig. 2D). Acetylated lysine residues of the sirtuin were subsequently identified by MS and are presented in Supplementary Table 2. Moreover, our result also showed that CobB

undergoes auto-deacetylation in vitro (Fig. 2D, Supplementary Table 1). It remains unknown if CobB acetylation is of physiological importance. However, neither Prs nor CobB acetylation had any impact on their protein-protein interaction compared to the wt and nonacetylated protein (Fig. 2C). This suggests that acetylated lysine residues

in Prs do not take part in its interaction with the CobB deacetylase. We further probed this by repeating the pull downs with purified Prs variants where the acetylable lysines K182, K194 and K231 were substituted by alanines. All three variants were still able to interact with CobB (Fig. 2EF). Corroborating those results, we found that CobB was pulled-down by Prs in $\triangle p a t Z$ and $\Delta p t a$ strains (Supplementary Table 1). The former strain is devoid of protein lysine acetyltranferase (Ma \& Wood, 2011), the latter lacks phosphate acetylase (Wolfe, 2005) which synthesizes acetyl phosphate. The two strains are characterized by decreased level of enzymatic and chemical acetylation, respectively (Schilling et al, 2015; Weinert et al, 2013). In summary, our results have shown that Prs and CobB form a complex and their interaction does not rely on Prs acetylation, nor is it influenced by the acetylation state of both proteins in vitro.

Prs stimulates the deacetylase activity of CobB and partially protects it from the inhibitory effect of nicotinamide. Next, we investigated the consequences of complex formation between Prs and CobB on their catalytic activity. Prs produces one of the key metabolites for the synthesis of NAD+(Hove-Jensen et al, 2017) (Fig. 1) which is a substrate of CobB in deacetylation. Therefore, a possible role of their interaction could be to orchestrate the sirtuin activity of the NAD+ metabolism. First, we investigated the effect of Prs-CobB assembly on CobB-mediated removal of acetyl groups from modified lysines. To elucidate this, we measured deacetylation rate of an artificial fluorogenic substrate for Zn2+ and NAD+ dependent deacetylases - MAL (BOC-Ac-Lys-AMC)(Heltweg et al, 2003). In the presence of Prs, CobB activity in deacetylating MAL was stimulated by about 50\% (Fig. 3A). The degree of stimulation was dependent on Prs concentration and reached maximum in 6:1 molar ratio 
bioRxiv preprint doi: https://doi.org/10.1101/2020.12.09.417477; this version posted December 9,2020 . The copyright holder for this preprint (which was not certified by peer review) is the author/funder, who has granted bioRxiv a license to display the preprint in perpetuity. It is made available under aCC-BY-NC-ND 4.0 International license.

of Prs to CobB (Prs monomer : CobB monomer). A further increase of Prs concentration had no effect on CobB activity, suggesting that Prs hexamers stimulate a single catalytic center of CobB. As expected, CobB deacetylase activity was dependent on NAD+ concentration and Prs enhanced it in a wide range of NAD+ concentrations, even in those lower than the physiological ones (Bennett et al, 2009) (Fig. 3B). Neither Prs substrates (ribose 5-phosphate, ATP) nor the products of its catalytic activity (PRPP, AMP) and allosteric inhibitor ADP, had significant impact on its biding to CobB or ameliorating deacetylation of MAL substrate (Supplementary Fig. 2). CobB, as other sirtuins, was shown to be sensitive to feedback inhibition by deacetylation reaction byproduct - nicotinamide (NAM), with IC $_{50}$ value estimated at approximately $52 \mu \mathrm{M}$ (Gallego-Jara et al, 2017) (Fig. 3C). NAM is also one of the metabolites of the E. coli NAD+ salvage pathway I and its intracellular level has been shown to fluctuate dependent on bacterial growth conditions (Gallego-Jara et al, 2017). This makes NAM a likely candidate for a regulator of CobB activity in vivo. Therefore, we tested how interaction with Prs affects NAM-mediated inhibition of CobB deacetylase activity. In the presence of Prs, deacetylation of MAL substrate by CobB was more effective even at very high NAM concentrations, indicating that Prs partially protects CobB from inhibition by NAM (Fig. 3D). We also confirmed using pull-down assay that CobB forms a complex with Prs in the presence of NAM (Supplementary Fig. 2).

Moreover, it has been shown previously that several metabolites of the NAD salvage pathways, like nicotinamide mononucleotide (NMN), can act as weak inhibitors of Sir2 family deacetylases in vitro (Schmidt et al, 2004). Corroborating those results, we observed that NMN, as well as nicotinic acid adenine dinucleotide (NaAD), NADH and NADP negatively influence CobB activity at high concentrations (Fig. 3C). As in the case of NAM, Prs increased CobB activity in the presence of those metabolites (Fig. 3D, Supplementary Fig. 3).

Those results suggest that Prs-CobB interaction influences catalytic activity of CobB by increasing its efficiency as a deacetylase. Formation of a complex with Prs also partially protects CobB from inhibition by NAM and other NAD+ metabolites, further suggesting that the interaction exerts an impact on the catalytic center of CobB.

Proteome acetylation is altered in strains producing of Prs variants K182A and K231A. PRPP, produced by Prs, is a necessary metabolite for de novo synthesis of nucleotides, cofactors, histidine and tryptophan (Hove-Jensen et al, 2017), making Prs an essential enzyme under standard bacterial growth conditions (Baba et al, 2006). Therefore, testing Prs influence on CobB activity in E. coli cells is challenging. However, we found that mutations in the prs gene, affecting acetylation of the PRPP synthase, result in profound changes in the global proteome acetylation level. To assess those alterations, we measured protein acetylation in $E$. coli cells, using Western blot and anti-N(E)-acetyl lysine antibody. Cells were sampled in middle-exponential phase, when overall acetylation is low, and also in early stationary phase, when protein acetylation increases (Schilling et al, 2015; Weinert et al, 2013). In those experiments, cells that chromosomally express prs variants K182A and K231A showed higher protein acetylation level than their wild-type counterpart upon entry to stationary phase (Fig. 4A). Since Prs produces a precursor for NAD+ synthesis changes in the enzyme's activity could affect intracellular NAD+ concentration, ultimately leading to differences in CobB-mediated protein deacetylation rate. Therefore, product synthesis by both Prs variants was measured in vitro, showing that Prs K231A had a similar activity as wild-type Prswhereas the activity of Prs K182A was slightly decreased (Fig. 4B). The latter result was also consistent with a slower growth rate of the cognate strain. Moreover, both variants stimulated CobB-mediated deacetylation of MAL substrate in vitro (Fig. 4C), confirming that they retain the activity of the wild-type protein. PRPP formation by Prs acetylated in vitro by acetyl 
phosphate was lower by about $15 \%$, whereas the main lysine residue acetylated under those conditions is K182 (Supplementary Fig. 4). Together, those results suggest that the increased protein lysine acetylation in strains producing Prs that does not undergo acetylation at positions 182 or 231 is unlikely to be a mere result of altered PRPP concentration. Further evidence that higher proteome acetylation level in those strains is connected to cooperation between Prs and CobB is provided by Western blot results obtained with double mutants prs (K182A or K231A) $\triangle \operatorname{cobB}$ (Fig. 4A). Protein acetylation profile of the double mutant, upon cell entry to the stationary phase, was practically indistinguishable from that of the single $\triangle \operatorname{cobB}$ mutant, particularly for the strain prs (K231A) $\Delta \operatorname{cobB}$, suggesting an epistatic effect (Fig. 4A). Mass spectrometry analysis of gel bands showing high acetylation signal after probing with anti-N $(\varepsilon)$-acetyl lysine antibody, revealed that their most prominent components were Lpd, Pgk and also GadA-GadB. All those proteins have been previously reported to be acetylated in vivo and their acetylation level was affected in a $\triangle c o b B$ mutant (Zhang et al, 2013; Castaño-Cerezo et al, 2014). Thus, our data corroborate previous findings of other groups and suggest that although Prs acetylation is not required for Prs-CobB interaction (Fig. 2CEF), it may play a role in vivo in sustaining CobB-mediated deacetylation rate during the stationary phase.

Lpd (lipoamide dehydrogenase) is a component of pyruvate dehydrogenase, $\alpha$-ketoglutarate dehydrogenase and the glycine cleavage system, taking part in glycolysis, TCA cycle and glycine catabolism, respectively (Carothers et al, 1989). Pgk (phosphoglycerate kinase) on the other hand, participates in glycolysis and gluconeogenesis (Nellemann et al, 1989), whereas GadA and GadB are homologous decarboxylases playing a major role in glutamate-dependent acid resistance system (Foster, 2004). Considering the role of identified proteins, our results also imply that Prs-CobB interplay is important for regulation of cellular energetics and the stress response.

CobB stimulates Prs activity in vitro under suboptimal conditions and impacts NAD+ metabolism in vivo. The results presented so far strongly suggest that formation of the PrsCobB complex impacts the rate of acetyl group removal from acetylated lysine residues. We next asked, whether assembly with CobB reciprocally influences Prs activity. Prs synthesizes PRPP from ribose 5-phosphate and ATP, producing AMP as a byproduct (Hove-Jensen et al, 2017). It utilizes magnesium and phosphate ions as a cofactor and allosteric activator, respectively (Willemoes et al, 2000). To assess Prs catalytic activity, we monitored AMP formation using a luciferase based assay that produces a luminescent signal proportional to AMP present in the samples.

Results of this assay showed that addition of CobB alone, CobB together with its substrate NAD+ or product NAM had little impact on Prs activity, when sufficient amount of magnesium and phosphate ions was provided (Supplementary Fig. 5). Conversely, when assays were carried out under conditions of low magnesium or phosphate concentration, CobB significantly stimulated Prs activity (Fig. 5A). This suggests that under suboptimal conditions for the Prs function, assembly with CobB may balance PRPP synthesis by Prs. The intracellular magnesium level has been previously implicated as one of the factors regulating protein acetylation in E. coli cells. Namely, protein acetylation was higher in cells grown in magnesium-limited media(Christensen et al, 2017). This effect could be due to insufficient CobB stimulation by Prs. However, at least in vitro, magnesium ions concentration had no impact on the enhancement of CobB-mediated deacetylation rate by Prs (Supplementary Fig. 6). Interaction with CobB also slightly enhanced feedback inhibition of Prs activity by PRPP (Fig. 5B). 
bioRxiv preprint doi: https://doi.org/10.1101/2020.12.09.417477; this version posted December 9,2020 . The copyright holder for this preprint (which was not certified by peer review) is the author/funder, who has granted bioRxiv a license to display the preprint in perpetuity. It is made available under aCC-BY-NC-ND 4.0 International license.

Together, those result show that, at least under certain conditions, formation of the complex with CobB may also influence Prs function.

NAD+ is a key cofactor of many enzymes and its concentration in E. coli cells is high, within millimolar range(Bennett et al, 2009). It has been demonstrated that in eukaryotic cells, NAD+ -consuming enzymes, including sirtuins, substantially contribute to NAD+ expenditure and impact NAD homeostasis (Strømland et al, 2019). This relationship in E. coli has not been investigated, whereas its existence would support the need of coupling between deacetylation and NAD+ biosynthesis and explain reciprocal effect of Prs and CobB on their activity. Therefore, we were interested whether the absence of CobB function will influence the level of NAD+ metabolites. We employed metabolomics to quantitatively assess the intracellular levels of those compounds in wild-type and $\triangle \operatorname{cobB}$ strains. Indeed, we observed that in absence of CobB, concentration of all metabolites of the NAD synthesis and salvage pathways were raised by about 25\% (Fig. 6), suggesting that CobB is an important player in NAD+ turnover.

\section{Discussion}

In this work we have provided evidence that the CobB deacetylase and the PRPP synthase form a complex in E. coli. (Supplementary Table 1, Fig. 2A) Within this complex, both proteins can affect each other's activity (Fig. 3, 5). Why would cells need such an ally? Lysine acetylation is a protein modification that affects protein activity. It allows cells to quickly adjust the available pool of active proteins in response to environmental cues, avoiding energy consuming degradation and synthesis. To be efficient as a fast, adaptable regulatory system, acetylation needs to be reversible. This is provided by the action of deacetylases, which in bacteria are mostly NAD+ -dependent. This makes NAD+ concentration a possible mean to regulate the rate of protein deacetylation. In eukaryotic cells, a clear link has been shown between sirtuins activity and processes influencing the level of NAD+ and its metabolites, like NAM (Lu \& Lin, 2010; Zhang \& Sauve, 2018; Anderson et al, 2017; Imai \& Guarente, 2016). Sirtuins activation has also been observed under various stress conditions, including low energy level manifested by ATP depletion (Kang et al, 2017; Nogueiras et al, 2012). Bacterial sirtuins have low $\mathrm{K}_{\mathrm{m}}$ values for NAD+ and prokaryotic cells lack compartmentalization that could ensure spatial regulation of NAD+ level. In addition, NADH is rather a weak inhibitor of CobB activity, whereas intracellular NADH concentration is around two orders of magnitude lower than that of NAD+ (Bennett et al, 2009). All those factors may limit the possibility of a direct regulation of CobB activity by NAD+ or $\mathrm{NAD} / \mathrm{NADH}$ ratio in bacterial cells. Dynamics of NAD+ synthesis under various growth conditions is poorly understood. Nevertheless, NAD+ synthesis de novo and through salvage pathways requires nicotinamide moiety, ribose phosphate, provided by PRPP, and adenine nucleotide. The two latter metabolites both link NAD+ and cellular energetics to Prs.

In the experiments described in this work we have not found conditions that would break the Prs-CobB complex or restrain its formation. We have also not identified factors that would disable Prs-mediated stimulation of CobB activity in vitro, and could therefore serve as regulators of the interaction. The known Prs inhibitors - ADP or PRPP had little effect on the cooperation between Prs and CobB (Supplementary Fig. 2). However, while the $c o b B$ gene is constitutively expressed (Castaño-Cerezo et al, 2011), prs is regulated at transcriptional level and activated by low purine and pyrimidine nucleotides concentration (He et al, 1993; White et al, 1971). Hence, the amount of Prs-CobB complexes formed in the cell and overall CobB deacetylation rate would depend on the demand to synthesize new purine nucleotides, including ATP precursors (Fig. 7). Moreover, several purine synthesis enzymes, like PurA and Adk were found among proteins acetylated in E. coli cells (Weinert et al, 2013; Zhang et 
bioRxiv preprint doi: https://doi.org/10.1101/2020.12.09.417477; this version posted December 9,2020 . The copyright holder for this preprint (which was not certified by peer review) is the author/funder, who has granted bioRxiv a license to display the preprint in perpetuity. It is made available under aCC-BY-NC-ND 4.0 International license.

al, 2013). The effect of acetylation on those enzymes has not been determined so far but acetylation has usually an inhibitory effect. Thus, transcriptional activation of prs could ultimately lead to more effective protein deacetylation by CobB and, among other effects, to an increase in the activity of purine synthesis pathway. At the same time, assembly with Prs would partially overcome inhibition of CobB by accumulating deacetylation product - NAM (Fig. 3D). In the stationary phase, Prs acetylation at lysines K182 and K231 could stimulate CobB activity (Fig. 4A) or have an effect on Prs stability, enabling an efficient interaction between the two proteins. In another direction, CobB stimulates Prs when magnesium or phosphate level fall to meet NAD+ demands (Fig. 5A).

In summary, the crosstalk between Prs and CobB allows E. coli cells to integrate various cues and adjust protein acetylation level to NAD+ metabolism.

\section{Methods}

\section{Materials, reagents and strains}

Primers used in this study were synthesized by Sigma/Merck. List of primers, vectors and strains is available in Supplementary table 3. Polymerases and enzymes used for cloning were purchased from Thermo Scientific or New England Biolabs. Reagents used for buffers were purchased from either Carl Roth or Bioshop Life Science. NAD ${ }^{+}$salvage pathway substrates were purchased from Sigma/Merck except for nicotinamide (NAM) which was purchased from Bioshop Life Science.

\section{Cloning, expression and purification of recombinant proteins}

His-Prs and catalytically inactive His-PrsK194A were expressed from pET28a-His-prs and pET28a-His-prsK194A vectors in E. coli Rosetta (DE3) as we described earlier (Walter et al, 2020). Additional point mutations replacing acetylated lysines K182 and K231 for alanines were introduced into pET28a-His-prs vector with phosphorylated primers (Walter et al, 2020). E. coli Rosetta (DE3) was transformed with pET28a-His-prsK231A, grown to $\mathrm{OD}_{600}$ between 0.8 and 1.0 and induced with $100 \mu \mathrm{M}$ Isopropyl $\beta$-D-1-thiogalactopyranoside (IPTG) at $37^{\circ} \mathrm{C}$ for $5 \mathrm{~h}$ in $2 \mathrm{xYT}$ medium (BioShop). E. coli BL21-DE3-pLysE was transformed with pET28A-His-prsK182A and induced at $\mathrm{OD}_{600}$ between 0.8 and 1.0 with $1 \mathrm{mM}$ IPTG at $37^{\circ} \mathrm{C}$ for $3 \mathrm{~h}$ in 2xYT medium.

The cobB sequence, amplified on E. coli MG1655 genomic DNA was N-terminally cloned with RF-cloning (Bond \& Naus, 2012) into modified pET28a-TEV vector (Walter et al, 2020). The E. coli Rosetta (DE3) was transformed with vector pET28a-His-TEV-cobB, grown in Terrific Broth (BioShop) to $\mathrm{OD}_{600}$ between 0.8 and 1.0 and induced with $200 \mu \mathrm{M}$ IPTG at $37^{\circ} \mathrm{C}$ for $5 \mathrm{~h}$.

His-Prs protein and its variants were purified at $20^{\circ} \mathrm{C}$, as described earlier (Walter et al, 2020) with buffer A (50 mM potassium phosphate $\mathrm{pH}$ 7.5, $10 \%$ glycerol, $500 \mathrm{mM} \mathrm{NaCl}, 20 \mathrm{mM}$ imidazole $\mathrm{pH}$ 7.8); buffer B (50 mM potassium phosphate $\mathrm{pH}$ 7.5, $10 \%$ glycerol, $500 \mathrm{mM}$ $\mathrm{NaCl}, 300 \mathrm{mM}$ imidazole $\mathrm{pH}$ 7.8, $0.5 \mathrm{mM}$ tris(2-carboxyethyl)phosphine (TCEP)) and dialysis SEC1 buffer (50 mM potassium phosphate $\mathrm{pH}$ 8.2, $10 \%$ glycerol, $500 \mathrm{mM} \mathrm{NaCl}$ ).

Non-acetylated CobB was purified on His-Trap columns (GE healthcare) as described above however, the lysate was loaded on the column and protein eluted on ice. Further, fractions containing protein were combined and diluted 1:1 with buffer A-0 (50 mM potassium phosphate $\mathrm{pH}$ 8.2, $10 \%$ glycerol) and supplemented with Dithiothreitol (DTT) and ethylenediaminetetraacetic acid (EDTA) to a final concentration $1 \mathrm{mM}$ and $0.5 \mathrm{mM}$ respectively. Aliquots of $20 \mathrm{ml}$ were made. TEV protease $(0.2 \mathrm{mg})$ purified in-house ${ }^{54}$ was added and incubated at $24{ }^{\circ} \mathrm{C}$ for $3 \mathrm{~h}$ with no shaking or rotation. After incubation, $\mathrm{NaCl}$ concentration was readjusted to $500 \mathrm{mM}$ by spiking with $5 \mathrm{M} \mathrm{NaCl}$ stock solution and protein 
bioRxiv preprint doi: https://doi.org/10.1101/2020.12.09.417477; this version posted December 9,2020 . The copyright holder for this preprint (which was not certified by peer review) is the author/funder, who has granted bioRxiv a license to display the preprint in perpetuity. It is made available under aCC-BY-NC-ND 4.0 International license.

solution was dialyzed overnight into SEC1 buffer at $4^{\circ} \mathrm{C}$ followed by protein separation from His tag on a His-Trap column (GE Healthcare), concentration with an Amicon Ultra 15 MWCO10kDa (Millipore) filter and size-exclusion chromatography at $4{ }^{\circ} \mathrm{C}$ on a Superdex 200 10/300 GL gel filtration column (GE Healthcare). Purity of the proteins was evaluated on SDS-PAGE gel. Concentrated to $10-15 \mathrm{mg} \mathrm{ml}^{-1}$ purified proteins were snap-frozen in liquid nitrogen and stored at $-70^{\circ} \mathrm{C}$.

\section{Acetylation of His-Prs and CobB proteins during protein purification}

His-Prs was purified on His-Trap columns (GE Healthcare) as described above and dialyzed overnight at $20{ }^{\circ} \mathrm{C}$ into $1 \mathrm{x}$ acetylation buffer $(100 \mathrm{mM}$ Tris- $\mathrm{HCl} \mathrm{pH} 7.5,10 \%$ glycerol, 150 $\mathrm{mM} \mathrm{NaCl}$ ) [modified from (Kuhn et al, 2014; Qin et al, 2016)]. Further, it was concentrated using the Amicon Ultra 15 MWCO30kDa (Millipore) filter at $18{ }^{\circ} \mathrm{C}$ to $4 \mathrm{mg} \mathrm{ml}^{-1}$ and acetylated with acetyl phosphate (lithium potassium salt, Sigma) at final concentration $20 \mathrm{mM}$ at $24{ }^{\circ} \mathrm{C}$ for $3 \mathrm{~h}$. Following acetylation, His-Prs was concentrated at $18{ }^{\circ} \mathrm{C}$ (Amicon Ultra 15 MWCO30kDa) to approximately $3-4 \mathrm{ml}$ and further purified by size-exclusion chromatography at $18{ }^{\circ} \mathrm{C}$ on Superdex 200 10/300 GL gel filtration column (GE Healthcare). His-TEV-CobB, prior to acetylation, was purified and washed on His-Trap columns (GE Healthcare) with buffer Ac (50 mM Tris pH 7.9, $500 \mathrm{mM} \mathrm{NaCl}, 20 \mathrm{mM}$ imidazole pH 7.8, 10 $\%$ glycerol) and eluted on ice with buffer Bc (50 mM Tris pH 7.9, $500 \mathrm{mM} \mathrm{NaCl}, 300 \mathrm{mM}$ imidazole $\mathrm{pH}$ 7.8, $10 \%$ glycerol). Fractions containing protein were combined, diluted 1:1 with buffer A-0 and supplemented with DTT $(1 \mathrm{mM})$, EDTA $(0.5 \mathrm{mM})$ and TEV protease (0.2 mg). Further, fractions were incubated for $3 \mathrm{~h}$ at $20^{\circ} \mathrm{C}$ as above, followed by overnight dialysis at $4^{\circ} \mathrm{C}$ into acetylation dialysis buffer (100 mM Tris, pH 8.2, $300 \mathrm{mM} \mathrm{NaCl}, 10 \%$ glycerol). The CobB protein was separated from His tag on His-Trap column (GE Healthcare), concentrated at $4{ }^{\circ} \mathrm{C}$ to $6 \mathrm{mg} \mathrm{ml}^{-1}$, diluted $1: 1$ in $0 \mathrm{x}$ acetylation buffer $(100 \mathrm{mM}$ Tris-HCl pH 7.5, $10 \%$ glycerol) and acetylated with acetyl phosphate at final concentration $20 \mathrm{mM}$ at $24{ }^{\circ} \mathrm{C}$ for $3 \mathrm{~h}$. Protein solution was further dialyzed overnight into SEC1 buffer at 4 ${ }^{\circ} \mathrm{C}$.

Purity of proteins was evaluated on $10 \%$ SDS-PAGE gel. Purified proteins, concentrated to $10-15 \mathrm{mg} \mathrm{ml}^{-1}$, were snap-frozen in liquid nitrogen and stored at $-70^{\circ} \mathrm{C}$. Acetylation was evaluated with Western blot probed with anti-acetyl lysine antibodies (1:800 dilution) (Sigma/Merck). Mass spectrometry outsourced to Mass Spectrometry Laboratory IBB PAN, Warsaw, Poland. Two independent batches of both His-PrsAc and CobBAc subjected to acetyl phosphate treatments were purified and acetylation was assessed.

\section{CobB pull-down on His-Prs and its variants.}

His-Prs or its variants $(10 \mu \mathrm{g})$ were bound to $4 \mu \mathrm{l}$ of Ni-NTA Magnetic Agarose Beads (Qiagen) in $50 \mu \mathrm{l}$ interaction buffer (50 mM Tris pH 9.0, $30 \mathrm{mM}$ imidazole $\mathrm{pH}$ 7.8, $300 \mathrm{mM}$ $\mathrm{NaCl}, 0.2 \%$ Tween $20,10 \%$ glycerol) for $1 \mathrm{~h}$ on vibrating mixer at $20^{\circ} \mathrm{C}$. Following triple wash with interaction buffer, $30 \mu \mathrm{g}$ of CobB was added to His-Prs bound to beads in $50 \mu \mathrm{l}$ fresh interaction buffer and incubated for $2 \mathrm{~h}$ on vibrating mixer at $20^{\circ} \mathrm{C}$. Beads were washed 4 times with interaction buffer and resuspended in $20 \mu \mathrm{l} 1 \mathrm{x}$ SDS loading dye (31.25 mM Tris $\mathrm{pH}$ 6.8, $10 \%$ glycerol, $1 \%$ SDS, bromophenol blue). Proteins were resolved by electrophoresis in $10 \%$ SDS-PAGE gel and visualized with Coomassie Brilliant Blue R250 staining. $4 \mu \mathrm{g}$ of His-Prs and CobB proteins were loaded on gel separately as control. The experiments were performed in 3 independent repeats and representative gels were shown in figures.

CobB deacetylase activity on MAL (BOC-Ac-Lys-AMC) substrate 
CobB deacetylase activity was measured as described earlier (Heltweg et al, 2003, 2005) as deacetylation of MAL substrate (Sigma/Merck), an artificial fluorogenic substrate for $\mathrm{Zn}^{2+}$ and $\mathrm{NAD}^{+}$-dependent deacetylases. Briefly, deacetylation of $8 \mathrm{nmol}$ MAL substrate by 320

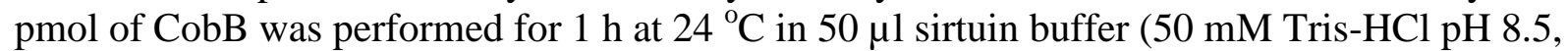
$137 \mathrm{mM} \mathrm{NaCl}, 2.7 \mathrm{mM} \mathrm{KCl}, 1 \mathrm{mM} \mathrm{MgCl}_{2}$ ) [modified from (Heltweg et al, 2003)] in presence of $\mathrm{NAD}^{+}$at final concentration $400 \mu \mathrm{M}$. The NAD ${ }^{+}$titration was performed in sirtuin buffer supplemented with $\mathrm{NAD}^{+}$independently at final concentrations $10 \mu \mathrm{M}, 20 \mu \mathrm{M}$, $50 \mu \mathrm{M}, 100 \mu \mathrm{M}, 250 \mu \mathrm{M}, 500 \mu \mathrm{M}, 750 \mu \mathrm{M}$ and $1 \mathrm{mM}$. The $\mathrm{MgCl}_{2}$ titration was performed in sirtuin buffer containing $400 \mu \mathrm{M} \mathrm{NAD}^{+}$and $\mathrm{MgCl}_{2}$ was supplemented independently at final concentrations $10 \mu \mathrm{M}, 20 \mu \mathrm{M}, 50 \mu \mathrm{M}, 100 \mu \mathrm{M}, 250 \mu \mathrm{M}, 500 \mu \mathrm{M}, 750 \mu \mathrm{M}, 1 \mathrm{mM}, 5 \mathrm{mM}$ and $10 \mathrm{mM}$. The effect of NAD ${ }^{+}$salvage pathway substrates was evaluated by adding $5 \mu \mathrm{l}$ of 50 $\mathrm{mM} \beta$-nicotinamide mononucleotide (NMN), nicotinamide (NAM), nicotinic acid (NA), nicotinic acid mononucleotide (NaMN), nicotinic acid adenine dinucleotide (NaAD) or 10 mM NADH, NADP, NADPH to the reaction. The effect of Prs influence on CobB activity was measured in sirtuin buffer by addition of 150 pmol, 300 pmol and 600 pmol of Prs hexamer. The effect of Prs influence on CobB activity in NAD+ titration assay, $\mathrm{MgCl}_{2}$ titration assay and in presence of $\mathrm{NAD}^{+}$salvage pathway substrates was measured by addition of $150 \mathrm{pmol}$ of Prs hexamer. All reactions were stopped by addition of $400 \mu \mathrm{l}$ of $1 \mathrm{M} \mathrm{HCl}$ and fluorescent substrate was extracted as an upper phase after vortexing for $30 \mathrm{~s}$ with $800 \mu \mathrm{l}$ ethyl acetate and centrifugation (9 $500 \mathrm{x} \mathrm{g}, 5 \mathrm{~min}$ ). Ethyl acetate was evaporated under the hood at $65{ }^{\circ} \mathrm{C}$ and the residue was dissolved in $600 \mu \mathrm{l}$ acetonitrile buffer (39.6 \% acetonitrile, $\left.5 \mu \mathrm{M} \mathrm{KH}{ }_{2} \mathrm{PO}_{4}, 4.6 \mu \mathrm{M} \mathrm{NaOH}\right)$. The fluorescence $(2 \times 250 \mu \mathrm{l})$ was measured at 330/390 nm in black, flat bottom 96 well plate (Heltweg et al, 2005). The experiments were repeated in at least 3 independent replicates.

\section{CobB deacetylase activity on His-PrsAc}

CobB driven deacetylation of His-PrsAc was analyzed by Western blot with anti-acetyl lysine antibodies (Sigma/Merck) and mass spectrometry. Briefly, CobB driven deacetylation of HisPrsAc was performed in sirtuin buffer (as above) for $1 \mathrm{~h}$ at $24^{\circ} \mathrm{C}$ in the presence of $400 \mu \mathrm{M}$ $\mathrm{NAD}^{+}$. Deacetylation of $147 \mathrm{pmol}$ Prs hexamer (30 $\mu \mathrm{g}$ of protein) was performed in $50 \mu \mathrm{l}$ reaction with $650 \mathrm{pmol}$ or $1940 \mathrm{pmol}$ CobB or CobBAc $(20 \mu \mathrm{g}$ and $60 \mu \mathrm{g}$ of protein respectively). The reaction was stopped by dilution in $4 \mathrm{x}$ SDS loading dye and 5 minutes incubation at $100^{\circ} \mathrm{C}$. Samples were resolved by electrophoresis in $10 \%$ SDS-PAGE gel in duplicates with one gel visualized with Coomassie Brilliant Blue R250 staining and the other transferred to PVDF membrane, probed with anti-acetyl lysine antibodies (1:800 dilution) and visualized. Selected bands were excised from the gel and outsourced for identification of protein lysine acetylation by mass spectrometry to Mass Spectrometry Laboratory IBB PAN, Warsaw, Poland. The experiments were repeated in at least 3 independent replicas and representative gels are shown in figures.

\section{Measurement of Prs catalytic activity}

The activity of Prs and its variants was measured as a luminescence signal from AMP formed during catalytic formation of PRPP from ribose-5-phosphate $(60 \mu \mathrm{M})$ and ATP $(60 \mu \mathrm{M})$ for $15 \mathrm{~min}$ at $37^{\circ} \mathrm{C}$. The assay was carried out with His-Prs protein and its variants His-PrsK194A, His-Prs-K182A and His-Prs-K231A, in $100 \mu \mathrm{MgCl}_{2}$ rich reaction buffer $(50 \mathrm{mM}$ Tris pH 8.0, $100 \mathrm{mM} \mathrm{KCl,} 13 \mathrm{mM} \mathrm{MgCl}_{2}$, $0.5 \mathrm{mM}$ K-phosphate pH 8.0, $0.5 \mathrm{mM}$ DTT, 0.1 $\mathrm{mg} \mathrm{mL}^{-1}$ BSA) at final Prs hexamer concentration $7 \mathrm{nM}(0.7$ pmol of hexamer per reaction, $142.8 \mathrm{ng}$ of protein per reaction).

The catalytic activity of His-Prs protein in the presence of CobB at various $\mathrm{MgCl}_{2}$ and potassium phosphate ( $\mathrm{pH}$ 8.0) concentrations was measured in $100 \mu$ l reaction buffer base (50 
bioRxiv preprint doi: https://doi.org/10.1101/2020.12.09.417477; this version posted December 9,2020 . The copyright holder for this preprint (which was not certified by peer review) is the author/funder, who has granted bioRxiv a license to display the preprint in perpetuity. It is made available under aCC-BY-NC-ND 4.0 International license.

mM Tris pH 8.0, $100 \mathrm{mM} \mathrm{KCl,} 0.5 \mathrm{mM}$ DTT, $0.1 \mathrm{mg} \mathrm{mL}^{-1}$ BSA) at final Prs hexamer concentration $7 \mathrm{nM}$ and CobB monomer concentration $40 \mathrm{nM}(4$ pmol of monomer per reaction, $124 \mathrm{ng}$ of protein per reaction). Reactions were supplemented with $1 \mathrm{mM}$ or $3 \mathrm{mM}$ potassium phosphate $\mathrm{pH} 8.0$ and / or $1 \mathrm{mM}$ or $3 \mathrm{mM} \mathrm{MgCl}_{2}$.

The activity of His-Prs in presence of various PRPP concentrations was measured in Prs

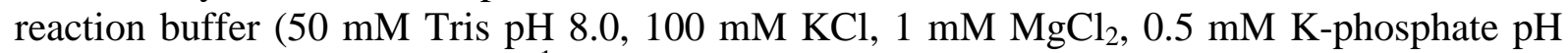
8.0, $0.5 \mathrm{mM}$ DTT, $0.1 \mathrm{mg} \mathrm{ml}^{-1} \mathrm{BSA}$ ) at final Prs hexamer concentration $7 \mathrm{nM}$ and CobB monomer concentration $40 \mathrm{nM}$.

Reactions were ceased by placing samples immediately after incubation on iced water. The concentration of AMP was measured with AMP-Glo ${ }^{\mathrm{TM}}$ Assay (Promega) according to manufacturer`s protocol. Briefly, the luminescence was measured for $10 \mu \mathrm{l}$ subsample after adding $10 \mu \mathrm{l}$ of AMP-Glo ${ }^{\mathrm{TM}}$ Reagent I which stopped the reaction, removed remaining ATP ( $1 \mathrm{~h}$ incubation at $24^{\circ} \mathrm{C}$ ) and converted AMP produced into ADP, followed by conversion of ADP to ATP through luciferase reaction with the AMP-Glo ${ }^{\mathrm{TM}}$ reagent II ( $1 \mathrm{~h}$ incubation at $24^{\circ} \mathrm{C}$ ). The luminescence was measured in white 96 well plate and the concentration of AMP in experimental samples was calculated based on AMP standard curve measured in triplicates. The catalytic activity of His-Prs protein variants was measured in two independent repeats while the activity in other conditions was measured in at least 3 independent experiments.

\section{Acetylation level in Prs mutants in-vivo}

Mutagenesis of MG1655 wild-type strain was performed with lambda Red recombineering as described earlier (Baba et al, 2006).

Strains with single mutations replacing acetylated lysine for alanine in prs gene: MG1655:prsK182A, MG1655:prsK231A; strain with cobB deletion MG1655: $\triangle$ cobB; and double mutant strains MG1655:prsK182A: $\operatorname{cobBKanR,~MG1655:prsK231A:\triangle cobBKanR~}$ were constructed by recombineering (Baba et al, 2006).

The acetylation level of the whole E. coli proteome was measured in TP7.3 medium $\left(10 \mathrm{~g} \mathrm{l}^{-1}\right.$ tryptone, buffered at $\mathrm{pH} 7.3$ with $100 \mathrm{mM}$ potassium phosphate) supplemented with $0.2 \%$ glucose at mid logarithmic phase $(6 \mathrm{~h})$ and early stationary phase (12 h). Bacterial cells (bacterial culture volume $=15 / \mathrm{OD}_{600}$ ) were harvested and the pellet was snap-frozen in liquid nitrogen. Frozen pellet was resuspended in $450 \mu$ lysis buffer ( $30 \mathrm{mM}$ Tris pH 6.8, $10 \%$ glycerol, $100 \mathrm{mM} \mathrm{NaCl}$ ) followed by $35 \mathrm{~s}$ sonication with pulsing on ice. Samples were centrifuged $10 \mathrm{~min}$ at $16000 \mathrm{x} \mathrm{g}, 4^{\circ} \mathrm{C}$ and protein concentration was measured with Bradford assay. Samples $(6 \mu \mathrm{g})$ were resolved by electrophoresis in $10 \%$ SDS-PAGE gel in duplicates, with first gel visualized with Coomassie brilliant blue and second transferred to PVDF membrane, probed with anti-acetyl lysine antibodies (1:800 dilution) and visualized. The representative gels and Western blots were repeated in at least 3 independent experiments. Selected bands were excised from gel and outsourced for mass spectrometry identification to Mass Spectrometry Laboratory IBB PAN, Warsaw, Poland.

\section{NAD+ metabolomics}

Metabolomics was performed by Creative Proteomics. Briefly, MG1655 strain and its $\triangle$ cobB strain were grown in $\mathrm{LB}$ medium with aeration at $37^{\circ} \mathrm{C}$ to $\mathrm{OD}_{600} \sim 0.3$. At this point $1 \mathrm{ml}$ of sample was withdrawn, cells pelleted and flash-frozen. For the measurements, the cell samples were thawed on ice and each sample (ca. $25 \mu \mathrm{L}$ ) was added with $25 \mu \mathrm{L}$ of an internal standard (IS) solution containing isotope-labeled NAD, NADH, NA and NAM. Cells were lysed with the aid of two 3-mm metal balls on a MM400 mill mixer for $1 \mathrm{~min}$ at $30 \mathrm{~Hz} .75 \mu \mathrm{L}$ of acetonitrile was then added. After vortexing for $10 \mathrm{~s}$ and sonication in an ice-water bath for $30 \mathrm{~s}$, the samples were centrifuged at $4^{\circ} \mathrm{C}$ to pellet protein. Clear supernatants were collected and the pellets were used for protein assay using a standard BCA procedure (Pierce). Standard 
solutions: a mixed standard solution containing all the targeted compounds were prepared at $20 \mathrm{nmol} / \mathrm{mL}$ in a mixture of IS solution - 50\% acetonitrile (1:4). This solution was serially diluted at 1 to $4(\mathrm{v} / \mathrm{v})$ with the same solution. A Waters Acquity UPLC system coupled to a 4000 QTRAP MS instrument was operated in the mode of multiple-reaction monitoring (MRM)/MS.

\section{Quantitation of NAD, NADH, NADP, NADPH, NaMN, NMN and NA}

$40 \mu \mathrm{L}$ of each supernatant or each standard solution was diluted 3 fold with water. $20-\mu \mathrm{L}$ aliquots of the resulting solutions were injected to run LC-MRM/MS with negative-ion detection on a C18 column (2.1x100 mm, 1.8 $\mu \mathrm{m})$ and with an ammonium formate buffer (A) and methanol (B) as the mobile phase for gradient elution (efficient gradient $5 \%$ to $50 \%$ B in $10 \mathrm{~min}$ ) at $0.3 \mathrm{~mL} / \mathrm{min}$ and $40^{\circ} \mathrm{C}$.

\section{Quantitation of NAM}

Mix $25 \mu \mathrm{L}$ of each supernatant or each standard solution with 4 volumes of $60 \%$ acetonitrile. $10 \mu \mathrm{L}$ aliquots of the resulting solutions were injected to run LC-MRM/MS with positive-ion detection on a HILIC column $(2.1 \times 100 \mathrm{~mm}, 1.7 \mu \mathrm{m})$ and with the use of $0.1 \%$ formic acid (A) and acetonitrile (B) as the mobile phase for gradient elution (efficient gradient $90 \%$ to $15 \% \mathrm{~B}$ in $12.5 \mathrm{~min}$ ) at $0.3 \mathrm{~mL} / \mathrm{min}$ and $30{ }^{\circ} \mathrm{C}$.

\section{Analytical Results}

Concentrations of detected compounds were calculated from the constructed linear-regression curve of each compound with internal standard calibration using the analyte-to-IS peak ratios measured from sample solutions.

\section{Acknowledgements}

The authors thank dr Ian Cadby and Krzysztof Sitko for assistance in some of the presented experiments. This work was supported by the National Science Center (Poland) [No. UMO2014/13/B/NZ2/01139 to M.G].

\section{Authors contribution}

B.W. performed majority of the experimental work, contributed to work conceptualization and preparation of the manuscript; J.M-O. performed the MS analysis of protein complexes and reviewed the manuscript; A.S. performed a part of the biochemical assays; M.B. contributed to project conceptualization and manuscript writing; A.L. contributed to establishment of protein assays and reviewed the manuscript; M.G. contributed to project conceptualization, data analysis and manuscript writing.

\section{Conflict of interest}

The authors declare no conflict of interest

\section{References}

Anderson KA, Madsen AS, Olsen CA \& Hirschey MD (2017) Metabolic control by sirtuins and other enzymes that sense NAD+, NADH, or their ratio. Biochim Biophys Acta Bioenerg 1858: 991-998 
bioRxiv preprint doi: https://doi.org/10.1101/2020.12.09.417477; this version posted December 9,2020 . The copyright holder for this preprint (which was not certified by peer review) is the author/funder, who has granted bioRxiv a license to display the preprint in perpetuity. It is made available under aCC-BY-NC-ND 4.0 International license.

Baba T, Ara T, Hasegawa M, Takai Y, Okumura Y, Baba M, Datsenko KA, Tomita M, Wanner BL \& Mori H (2006) Construction of Escherichia coli K-12 in-frame, singlegene knockout mutants: The Keio collection. Mol Syst Biol 2

Babu M, Butland G, Pogoutse O, Li J, Greenblatt JF \& Emili A (2009) Sequential peptide affinity purification system for the systematic isolation and identification of protein complexes from Escherichia coli. Methods Mol Biol 564: 373-400

Bennett BD, Kimball EH, Gao M, Osterhout R, Van Dien SJ \& Rabinowitz JD (2009) Absolute metabolite concentrations and implied enzyme active site occupancy in Escherichia coli. Nat Chem Biol 5: 593-599

Bernal V, Castaño-Cerezo S, Gallego-Jara J, Écija-Conesa A, de Diego T, Iborra JL \& Cánovas M (2014) Regulation of bacterial physiology by lysine acetylation of proteins. N Biotechnol 31: 586-595

Bond SR \& Naus CC (2012) RF-Cloning.org: An online tool for the design of restriction-free cloning projects. Nucleic Acids Res 40: 209-213

Butland G, Peregrin-Alvarez JM, Li J, Yang W, Yang X, Canadien V, Starostine A, Richards D, Beattie B, Krogan N, et al (2005) Interaction network containing conserved and essential protein complexes in Escherichia coli. Nature 433: 531-537

Carothers DJ, Pons G \& Patel MS (1989) Dihydrolipoamide dehydrogenase: functional similarities and divergent evolution of the pyridine nucleotide-disulfide oxidoreductases. Arch Biochem Biophys 268: 409-425

Castaño-Cerezo S, Bernal V, Blanco-Catalá J, Iborra JL \& Cánovas M (2011) cAMP-CRP coordinates the expression of the protein acetylation pathway with central metabolism in Escherichia coli. Mol Microbiol 82: 1110-1128

Castaño-Cerezo S, Bernal V, Post H, Fuhrer T, Cappadona S, Sánchez-Díaz NC, Sauer U, Heck AJ, Altelaar AM \& Cánovas M (2014) Protein acetylation affects acetate metabolism, motility and acid stress response in Escherichia coli . Mol Syst Biol 10: 762

Choudhary C, Weinert BT, Nishida Y, Verdin E \& Mann M (2014) The growing landscape of lysine acetylation links metabolism and cell signalling. Nat Rev Mol Cell Biol 15: 536550

Christensen DG, Orr JS, Rao C V \& Wolfe AJ (2017) Increasing Growth Yield and Decreasing Acetylation in Escherichia coli by Optimizing the Carbon-to-Magnesium Ratio in Peptide-Based Media. Appl Environ Microbiol 83

Christensen DG, Xie X, Basisty N, Byrnes J, McSweeney S, Schilling B \& Wolfe AJ (2019) Post-translational Protein Acetylation: An elegant mechanism for bacteria to dynamically regulate metabolic functions. Front Microbiol 10: 1-22

Colak G, Xie Z, Zhu AY, Dai L, Lu Z, Zhang Y, Wan X, Chen Y, Cha YH, Lin H, et al (2013) Identification of lysine succinylation substrates and the succinylation regulatory enzyme CobB in escherichia coli. Mol Cell Proteomics 12: 3509-3520

Dong H, Zhai G, Chen C, Bai X, Tian S, Hu D, Fan E \& Zhang K (2019) Protein lysine de-2hydroxyisobutyrylation by CobB in prokaryotes. Sci Adv 5: eaaw6703

Foster JW (2004) Escherichia coli acid resistance: Tales of an amateur acidophile. Nat Rev Microbiol 2: 898-907

Gallego-Jara J, Conesa AÉ, Puente T de D, Terol GL \& Díaz MC (2017) Characterization of CobB kinetics and inhibition by nicotinamide. PLoS One 12: 1-19

Gazzaniga F, Stebbins R, Chang SZ, McPeek MA \& Brenner C (2009) Microbial NAD Metabolism: Lessons from Comparative Genomics. Microbiol Mol Biol Rev 73: 529-541

Greiss S \& Gartner A (2009) Sirtuin/Sir2 phylogeny, evolutionary considerations and structural conservation. Mol Cells 28: 407-415

Guan X, Lin P, Knoll E \& Chakrabarti R (2014) Mechanism of inhibition of the human sirtuin enzyme SIRT3 by nicotinamide: Computational and experimental studies. PLoS One 9 
bioRxiv preprint doi: https://doi.org/10.1101/2020.12.09.417477; this version posted December 9,2020 . The copyright holder for this preprint (which was not certified by peer review) is the author/funder, who has granted bioRxiv a license to display the preprint in perpetuity. It is made available under aCC-BY-NC-ND 4.0 International license.

He B, Choi KY \& Zalkin H (1993) Regulation of Escherichia coli glnB, prsA, and speA by the purine repressor. J Bacteriol 175: 3598 LP - 3606

Heltweg B, Dequiedt F, Verdin E \& Jung M (2003) Nonisotopic substrate for assaying both human zinc and NAD+-dependent histone deacetylases. Anal Biochem 319: 42-48

Heltweg B, Trapp J \& Jung M (2005) In vitro assays for the determination of histone deacetylase activity. Methods 36: 332-337

Hove-Jensen B, Andersen KR, Kilstrup M, Martinussen J, Switzer RL \& Willemoes M (2017) Phosphoribosyl Diphosphate (PRPP): Biosynthesis, Enzymology, Utilization, and Metabolic Significance. Microbiol Mol Biol Rev 81

Imai S \& Guarente L (2010) Ten years of NAD-dependent SIR2 family deacetylases: implications for metabolic diseases. Trends Pharmacol Sci 31: 212-220

Imai SI \& Guarente L (2016) It takes two to tango: Nad+ and sirtuins in aging/longevity control. npj Aging Mech Dis 2: 1-6

James Theoga Raj C \& Lin SJ (2019) Cross-talk in NAD+ metabolism: insights from Saccharomyces cerevisiae. Curr Genet 65: 1113-1119

Kang H, Oka S, Lee D-Y, Park J, Aponte AM, Jung Y-S, Bitterman J, Zhai P, He Y, Kooshapur H, et al (2017) Sirt1 carboxyl-domain is an ATP-repressible domain that is transferrable to other proteins. Nat Commun 8: 15560

Kuhn ML, Zemaitaitis B, Hu LI, Sahu A, Sorensen D, Minasov G, Lima BP, Scholle M, Mrksich M, Anderson WF, et al (2014) Structural, kinetic and proteomic characterization of acetyl phosphate-dependent bacterial protein acetylation. PLoS One 9

Landry J, Sutton A, Tafrov ST, Heller RC, Stebbins J, Pillus L \& Sternglanz R (2000) The silencing protein SIR2 and its homologs are NAD-dependent protein deacetylases. Proc Natl Acad Sci U S A 97: 5807-5811

Lima BP, Antelmann H, Gronau K, Chi BK, Becher D, Brinsmade SR \& Wolfe AJ (2011) Involvement of protein acetylation in glucose-induced transcription of a stressresponsive promoter. Mol Microbiol 81: 1190-1204

Liu CX, Wu FL, Jiang HW, He X, Guo SJ \& Tao SC (2014) Global identification of CobB interactors by an Escherichia coli proteome microarray. Acta Biochim Biophys Sin (Shanghai) 46: 548-555

Liu W, Tan Y, Cao S, Zhao H, Fang H, Yang X, Wang T, Zhou Y, Yan Y, Han Y, et al (2018) Protein Acetylation Mediated by YfiQ and CobB Is Involved in the Virulence and Stress Response of \&lt;span class=\&quot;named-content genus-species\&quot; id=\&quot;named-content-1\&quot;\&gt; Yersinia pestis\&lt;/span\&gt; Infect Immun 86: e00224-18

Lu SP \& Lin SJ (2010) Regulation of yeast sirtuins by NAD+ metabolism and calorie restriction. Biochim Biophys Acta - Proteins Proteomics 1804: 1567-1575

Ma Q \& Wood TK (2011) Protein acetylation in prokaryotes increases stress resistance. Biochem Biophys Res Commun 410: 846-851

Nellemann LJ, Holm F, Atlung T \& Hansen FG (1989) Cloning and characterization of the Escherichia coli phosphoglycerate kinase (pgk) gene. Gene 77: 185-191

Nogueiras R, Habegger KM, Chaudhary N, Finan B, Banks AS, Dietrich MO, Horvath TL, Sinclair DA, Pfluger PT \& Tschöp MH (2012) Sirtuin 1 and sirtuin 3: physiological modulators of metabolism. Physiol Rev 92: 1479-1514

Qin R, Sang Y, Ren J, Zhang Q, Li S, Cui Z \& Yao Y-F (2016) The Bacterial Two-Hybrid System Uncovers the Involvement of Acetylation in Regulating of Lrp Activity in Salmonella Typhimurium .Front Microbiol 7: 1864 (https://www.frontiersin.org/article/10.3389/fmicb.2016.01864) [PREPRINT]

Rowland EA, Greco TM, Snowden CK, McCabe AL, Silhavy TJ \& Cristea IM (2017) Sirtuin Lipoamidase Activity Is Conserved in Bacteria as a Regulator of Metabolic Enzyme 
Complexes. MBio 8

Schilling B, Christensen D, Davis R, Sahu AK, Hu LI, Walker-Peddakotla A, Sorensen DJ, Zemaitaitis B, Gibson BW \& Wolfe AJ (2015) Protein acetylation dynamics in response to carbon overflow in Escherichia coli. Mol Microbiol 98: 847-863

Schmidt MT, Smith BC, Jackson MD \& Denu JM (2004) Coenzyme specificity of Sir2 protein deacetylases. Implications for physiological regulation. J Biol Chem 279: 4012240129

Strømland Ø, Niere M, Nikiforov AA, VanLinden MR, Heiland I \& Ziegler M (2019) Keeping the balance in NAD metabolism. Biochem Soc Trans 47: 119-130

Thao S, Chen CS, Zhu H \& Escalante-Semerena JC (2010) NE-lysine acetylation of a bacterial transcription factor inhibits its DNA-binding activity. PLoS One 5

Tsang AW \& Escalante-Semerena JC (1998) CobB, a new member of the SIR2 family of eucaryotic regulatory proteins, is required to compensate for the lack of nicotinate mononucleotide:5,6-dimethylbenzimidazole phosphoribosyltransferase activity in cobT mutants during cobalamin biosynthesis in Sal. J Biol Chem 273: 31788-31794

Venkat S, Gregory C, Sturges J, Gan Q \& Fan C (2017) Studying the Lysine Acetylation of Malate Dehydrogenase. J Mol Biol 429: 1396-1405

Walter BM, Szulc A \& Glinkowska MK (2020) Reliable method for high quality His-tagged and untagged E. coli phosphoribosyl phosphate synthase (Prs) purification. Protein Expr Purif 169

Weinert BT, Iesmantavicius V, Wagner SA, Schölz C, Gummesson B, Beli P, Nyström T \& Choudhary C (2013) Acetyl-Phosphate is a critical determinant of Lysine Acetylation in E.coli. Mol Cell 51: 265-272

Weinert BT, Satpathy S, Hansen BK, Lyon D, Jensen LJ \& Choudhary C (2017) Accurate quantification of site-specific acetylation stoichiometry reveals the impact of Sirtuin deacetylase CobB on the E. coli acetylome. Mol Cell Proteomics 16: 759-769

White MN, Olszowy J \& Switzer RL (1971) Regulation and mechanism of phosphoribosylpyrophosphate synthetase: repression by end products. J Bacteriol 108 : 122-131

Willemoes M, Hove-Jensen B \& Larsen S (2000) Steady state kinetic model for the binding of substrates and allosteric effectors to Escherichia coli phosphoribosyl-diphosphate synthase. J Biol Chem 275: 35408-35412

Wolfe AJ (2005) The acetate switch. Microbiol Mol Biol Rev 69: 12-50

Xu Z, Zhang H, Zhang X, Jiang H \& Liu C Interplay between the protein deacetylase CobB and second messenger c-di-GMP signaling.

Zhang K, Zheng S, Yang JS, Chen Y \& Cheng Z (2013) Comprehensive Profiling of Protein Lysine Acetylation in Escherichia coli. J Proteome Res 12: 844-851

Zhang N \& Sauve AA (2018) Regulatory Effects of NAD+ Metabolic Pathways on Sirtuin Activity. Prog Mol Biol Transl Sci 154: 71-104

Zhang Q, Zhou A, Li S, Ni J, Tao J, Lu J, Wan B, Li S, Zhang J, Zhao S, et al (2016) Reversible lysine acetylation is involved in DNA replication initiation by regulating activities of initiator DnaA in Escherichia coli. Sci Rep 6: 1-23

Zhao K, Chai X \& Marmorstein R (2004) Structure and Substrate Binding Properties of cobB, a Sir2 Homolog Protein Deacetylase from Escherichia coli. J Mol Biol 337: 731-741

\section{Figure legends}


bioRxiv preprint doi: https://doi.org/10.1101/2020.12.09.417477; this version posted December 9,2020 . The copyright holder for this preprint (which was not certified by peer review) is the author/funder, who has granted bioRxiv a license to display the preprint in perpetuity. It is made available under aCC-BY-NC-ND 4.0 International license.

Figure 1. NAD+ producing and consuming pathways in $\boldsymbol{E}$. coli. NAD+ de novo synthesis from aspartate (thin black arrows) and salvage pathways in E. coli:, I (represented jointly by dark and light gray arrows), II (shown by dark gray arrows), IV (from nicotinamide riboside, depicted by thick black arrows). Names of the enzymes engaged in NAD+ metabolism were provided next to the arrows depicting respective reactions. CobB and Prs role in NAD+ transformations is shown. Prs catalyzes PRPP biosynthesis which serves as a substrate for $\mathrm{NAD}+$ formation de-novo from aspartic acid and in NAD+ salvage pathways. NAD+ is essential for CobB mediated protein deacetylation. NAM is a byproduct of this reaction.

NAD - nicotinamide adenine dinucleotide, NMN - nicotinamide mononucleotide; NAM nicotinamide, NA - nicotinic acid, NAMN - nicotinic acid mononucleotide, NaAD nicotinate adenine dinucleotide, NR - nicotinamide ribonucleotide, R5P - ribose 5-phospahte, PRPP - phosphoribosyl pyrophosphate, Asp - aspartate

Figure 2. CobB and Prs form a complex in vitro irrespective of their acetylation status.

(A) $\mathrm{His}_{6}$-Prs interacts with CobB in a pull-down assay. $\mathrm{His}_{6}$-Prs was pre-bound to $\mathrm{Ni}^{2+-}$ coated magnetic beads. After washing off the excess of Prs, the beads were incubated with CobB. Unbound protein was removed by washing and the beads were resuspended in a loading dye and separated in 10\% SDS-PAGE gel. Lane 3 shows the extent of CobB binding to magnetic beads in the absence of the bait.

(B) Prs and CobB can be acetylated in vitro with acetyl phosphate. Prs and CobB were acetylated in the presence of $20 \mathrm{mM}$ acetyl phosphate and excess of the reagent was dialyzed. Acetylation was confirmed by Western blot with anti-acetyl lysine antibodies.

(C) Chemically acetylated Prs interacts with CobB . Interaction of acetylated proteins was tested in vitro in a pull-down assay, as above. The presence of acetylated protein in a reaction was marked with Ac.

(D) Acetylated Prs (Ac) becomes deacetylated in vitro by CobB. Acetylated Prs and CobB were incubated in the presence of $400 \mu \mathrm{M}$ NAD $+(1 \mathrm{~h})$. Proteins were separated in $10 \%$ SDSPAGE gel and Western blot with anti-acetyl lysine antibodies was subsequently performed. Numbers below the blot image represent the results of densitometric analysis of bands intensity from three independent blots.

(E) Prs variants with key acetylable lysine residues substituted by alanines interact with CobB and (F) acetylated CobB (Ac). Protein binding was assessed in a pull-down assay, as described above.

Figure 3. Prs stimulates the CobB deacetylase activity and partially overcomes NAMmediated inhibition.

(A) Prs stimulates deacetylation of MAL substrate by CobB. Deacetylation of MAL substrate ( $8 \mathrm{nmol}$ ) by CobB (320 pmol) in the presence and absence of indicated amounts of Prs (as a hexamer) was performed for $1 \mathrm{~h}$. Fluorescent substrate was extracted with ethyl acetate and fluorescence was measured at 330/390 nm in a plate reader. Error bars represent SD between 3 independent experiments.

(B) Prs stimulates CobB activity in a wide range of NAD+ concentrations. The assay of MAL deacetylation was performed as described above in the presence of Prs $(6 \mu \mathrm{M})$ and indicated amounts of NAD+. Mean values of 3 independent experiments were presented. Error bars show SD between the repeats.

(C) The effect of NAD+ metabolites on CobB activity. Deacetylation of MAL substrate by CobB was measured as described above, in the presence of indicated metabolites at $5 \mathrm{mM}$ (NMN, NAM, NaMN, NaAD) or 1mM concentration (NADH, NADP, NADPH). Mean values of 3 independent experiments were presented. Error bars show SD between repeats. 
bioRxiv preprint doi: https://doi.org/10.1101/2020.12.09.417477; this version posted December 9,2020 . The copyright holder for this preprint (which was not certified by peer review) is the author/funder, who has granted bioRxiv a license to display the preprint in perpetuity. It is made available under aCC-BY-NC-ND 4.0 International license.

(D) Prs partially overcomes inhibition of CobB by NAM. MAL deacetylation was performed as described above in the presence of indicated amounts of NAM and NMN and Prs $(3 \mu \mathrm{M})$. Mean values of 3 independent experiments were presented. Error bars show SD between the repeats.

Figure 4. Prs variants K182A and K231A affect protein acetylation level in vivo.

(A) Global protein acetylation was assessed in MG1655 strain and its $\triangle \operatorname{cobB}$ derivative, producing wild-type Prs or its K182A and K231A variant from the prs gene in its native chromosomal position. Overnight cultures of the strains were diluted in TP7.3 medium with $0.2 \%$ glucose and samples were collected after 6 and 12 hrs of cell growth. After preparation of whole cell lysates, $6 \mu \mathrm{g}$ of proteins from each of them was separated in 10\% SDS-PAGE gel, followed by Western blot with anti-acetyl lysine antibodies.

(B) Prs variants K182A and K231A are active in PRPP synthesis in vitro. Prs activity was assessed by measuring AMP formation from ribose 5-phospate $(60 \mu \mathrm{M})$ and ATP $(60 \mu \mathrm{M})$. After termination of Prs reaction, AMP was converted to ADP and the residual ATP was removed. Next, ATP was produced from ADP and utilized in luciferase reaction. Reactions were performed in 96-well plates and luminescence was measured using plate reader. Mean values of 2 independent experiments were presented. Error bars show SE between the repeats. (C) Prs variants K182A, K194A and K231A stimulate CobB deacetylase activity in vitro. Deacetylation of MAL substrate $(8 \mathrm{nmol})$ by CobB $(320 \mathrm{pmol})$ in the presence and absence of Prs $(6 \mu \mathrm{M}$ as a hexamer) was performed for $1 \mathrm{~h}$. Fluorescent substrate was extracted with ethyl acetate and fluorescence was measured at 330/390 $\mathrm{nm}$ in a plate reader. Mean values of 3 independent experiments were presented. Error bars show SD between the repeats.

\section{Figure 5. CobB stimulates Prs activity in vitro under conditions of low phosphate or} magnesium ion concentration.

(A) Prs reaction was performed in the presence of CobB (1:1 hexamer : monomer ratio) and Mg2+ and PO4- at indicated concentrations. Prs activity was assessed by measuring AMP formation from ribose 5-phospate $(60 \mu \mathrm{M})$ and ATP $(60 \mu \mathrm{M})$. After termination of Prs reaction, AMP was converted to ADP and the residual ATP was removed. Next, ATP was produced from ADP and utilized in luciferase reaction. Reactions were performed in 96-well plates and luminescence was measured using plate reader. Mean values of 3 independent experiments were presented. Error bars show SD between the repeats.

(B) CobB slightly increases Prs sensitivity to feedback inhibition by PRPP. Prs activity was measured as described above in the presence of indicated concentrations of PRPP. All measurements were taken in at least 3 independent repeats. Error bars show SD between the repeats.

Figure 6. Deletion of the $\operatorname{cobB}$ gene increases the level of NAD+ metabolites. MG1655 wild-type strain and its $\triangle \operatorname{cobB}$ derivative were grown in LB medium at $37^{\circ} \mathrm{C}$ with aeration. 1 $\mathrm{ml}$ of the cultures was collected at $\mathrm{OD}_{600} \sim 0.3$ and disrupted in the presence of isotope-labeled standards. Metabolites were extracted with acetonitrile (1:3) and detected with LC-MRM/MS. Concentrations of detected compounds were calculated from the constructed linear-regression curve of each compound with internal standard (IS) calibration using the analyte-to-IS peak ratios measured from sample solutions. Protein concentration was measured with bicinchronic acid kit and protein amount in the sample was taken as proxy of cellular mass present in the sample.

Figure 7. Overview of the interplay between CobB deacetylase and the PRPP synthase Prs in E. coli cells. Prs and CobB form a complex in E. coli cells which stimulates CobB 
839 deacetylase activity. The number of Prs-CobB complexes depends on transcriptional activity of the prs gene, which can be stimulated under conditions of low purine and pyrimidine nucleotides. Prs acetylation in the stationary phase is required for CobB stimulation. CobB in turn protects Prs form loss of activity under conditions of low magnesium or phosphate ion concentration.

844 


\begin{tabular}{|c|c|c|c|c|c|}
\hline \multirow{3}{*}{$\begin{array}{l}\text { Lysine } \\
\text { K182 }\end{array}$} & \multirow{3}{*}{$\begin{array}{c}\text { Protein sequence } \\
\text { VVRARAIAKLLNDTDMA }\end{array}$} & \multicolumn{2}{|l|}{ PrsAc } & \multicolumn{2}{|c|}{$\begin{array}{l}\text { PrsAc after CobB } \\
\text { deacetylation }\end{array}$} \\
\hline & & sample1 (6/8) & $75 \%$ & sample3 (2/34) & $6 \%$ \\
\hline & & sample2 (16/19) & $84 \%$ & sample4 (5/54) & $9 \%$ \\
\hline & & average & $80 \%$ & average & $8 \%$ \\
\hline \multirow{3}{*}{ K194 } & \multirow{3}{*}{ DTDMAIIDKRRPRANVSQ } & sample1 (11/69) & $16 \%$ & sample3 (3/57) & $5 \%$ \\
\hline & & sample2 (27/251) & $11 \%$ & sample4 (0/86) & $0 \%$ \\
\hline & & average & $14 \%$ & average & NA \\
\hline \multirow{3}{*}{ K231 } & \multirow{3}{*}{ IDTGGTLCKAAEALKERG } & sample1 (2/24) & $8 \%$ & sample3 (0/19) & $0 \%$ \\
\hline & & sample2 (0/34) & $0 \%$ & sample4 (0/19) & $0 \%$ \\
\hline & & average & NA & average & NA \\
\hline
\end{tabular}

Table 1. Acetylated lysines in Prs and their deacetylation by CobB. Chemically acetylated lysines K182, K194, K231 are deacetylated in-vitro by CobB deacetylase.

Samples of PrsAc and PrsAc deacetylated by CobB (Fig. 2D) were excised from 2 independent Coomassie stained SDS-Polyacrylamide gels and analyzed with Mass Spectrometry. All identified peptides carrying lysines of interest were summed up (second value in brackets) and acetylated lysines were counted (first value in brackets). The acetylation percentage was calculated and average values are shown in the table. A PrsAc protein sample aliquot was additionally analyzed with mass spectrometry where 108, 82 and 73 peptides with acetylated lysines K182, K194 and K231 respectively were identified suggesting those lysines were acetylated in-vitro. 


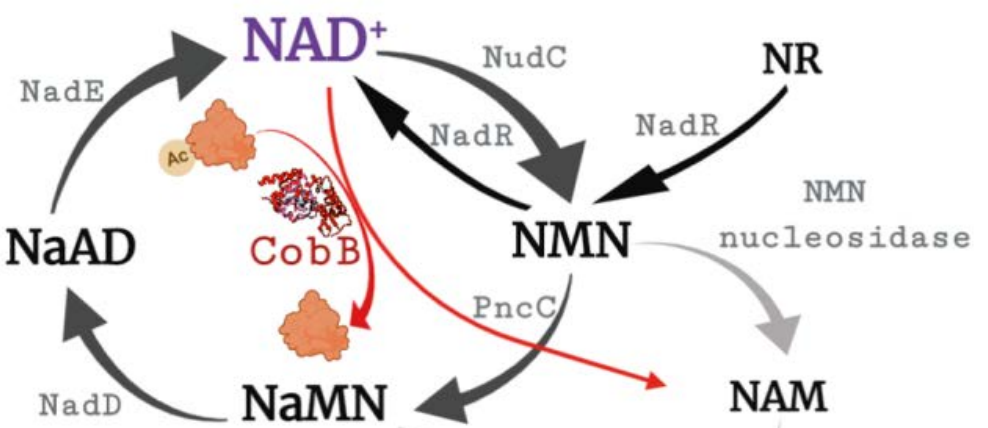

933

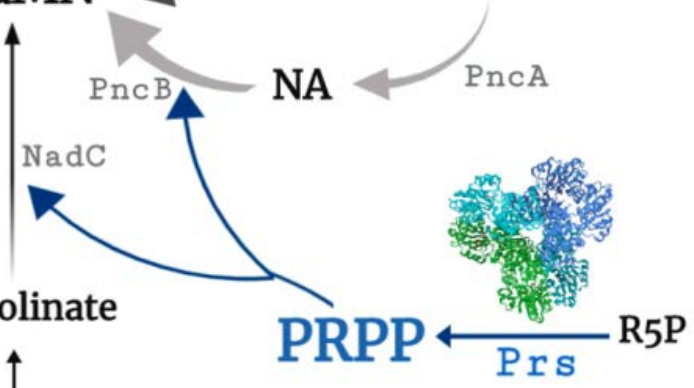

\section{quinolinate}

NadA

2-iminosuccinate

937 
bioRxiv preprint doi: https://doi.org/10.1101/2020.12 09.417477; this version posted December 9 2020. The copyright holder for this preprint (which was not certified by peer review) is the author/funder, who has granted bioRxiv a license to display the preprint in perpetuity. It is made available under aCC-BY-NC-ND 4.0 International license.

a

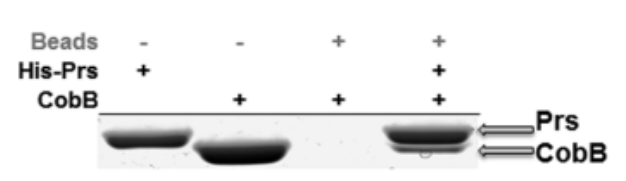

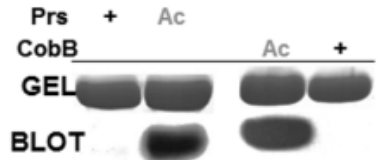

952

953

954

955

956

957

958

959

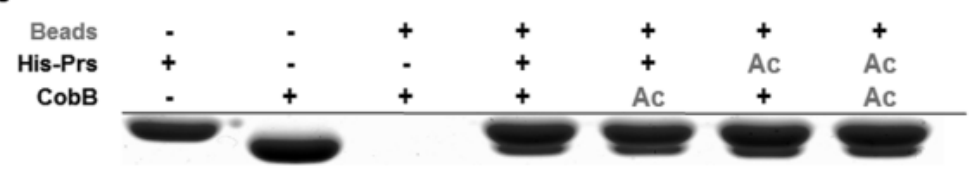

d

960

961

962

963

964

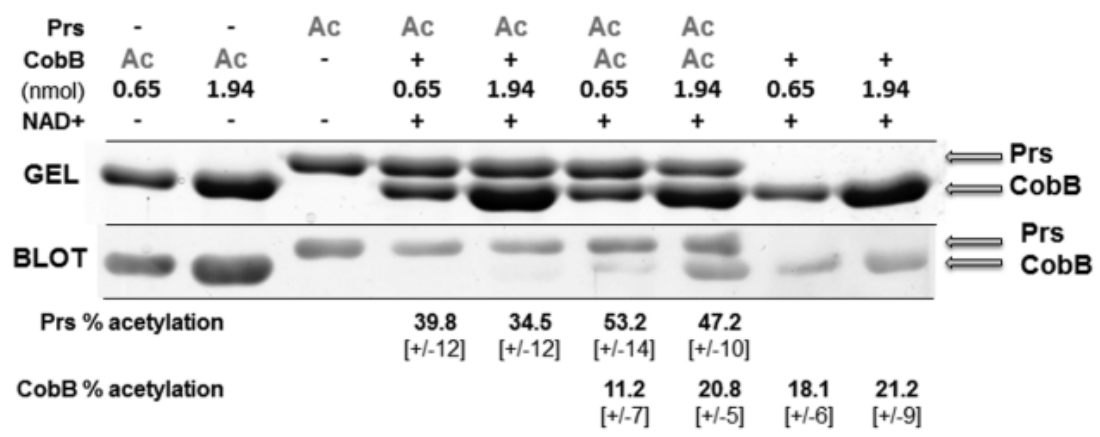

e

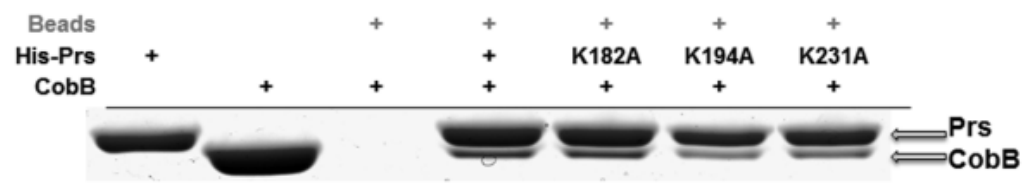

965

966

967

968

Fig. 2

969

970 
bioRxiv preprint doi: https:/doi.org/10.1101/2020.12.09.417477: this version posted December 9,2020 . The copyright holder for this preprint (which was not certified by peer review) is the author/funder, who has granted bioRxiv a license to display the preprint in perpetuity. It is made available under aCC-BY-NC-ND 4.0 International license.

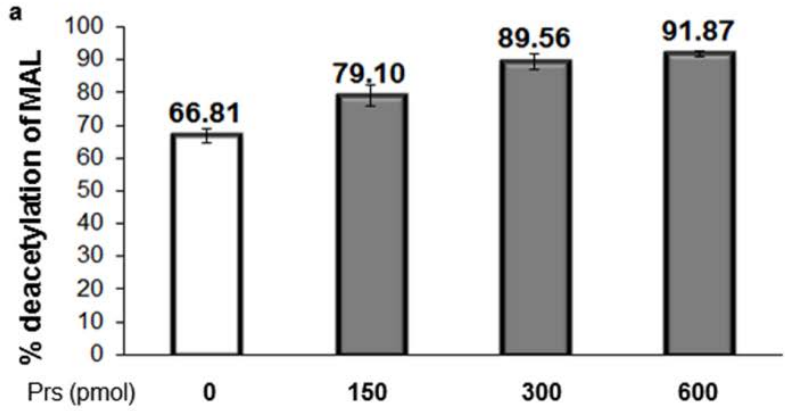

c

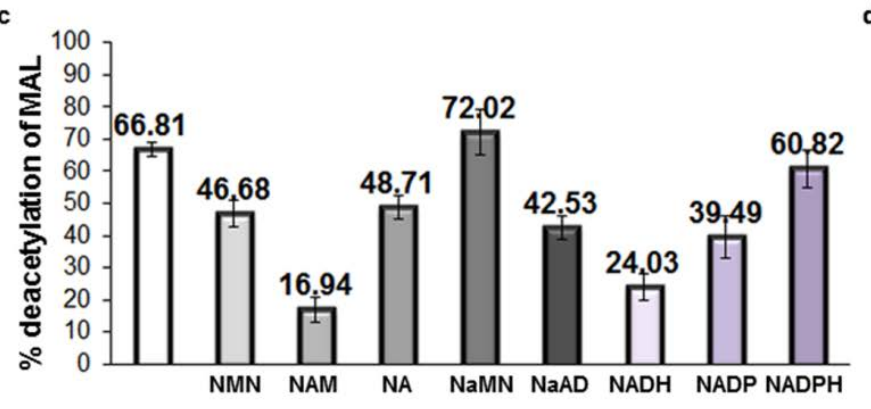

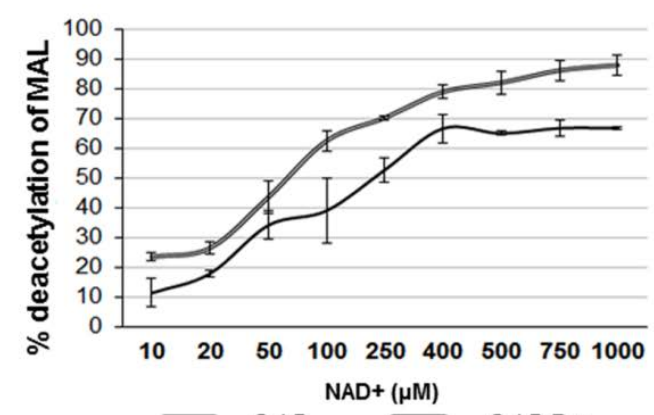

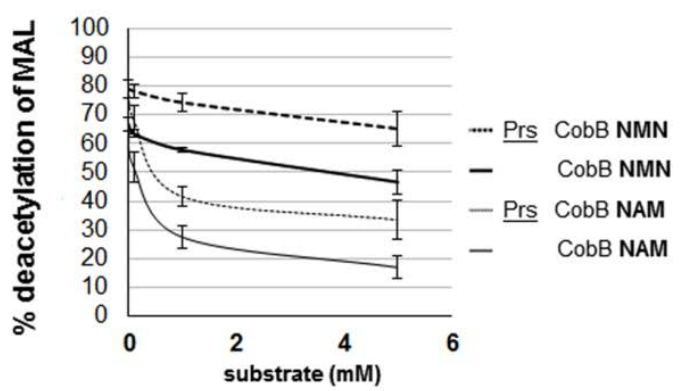


bioRxiv preprint doi: https:/doi.org/10.1101/2020.12.09.417477: this version posted December 9 2020. The copyright holder for this preprint (which was not certified by peer review) is the author/funder, who has granted bioRxiv a license to display the preprint in perpetuity. It is made available under aCC-BY-NC-ND 4.0 International license.
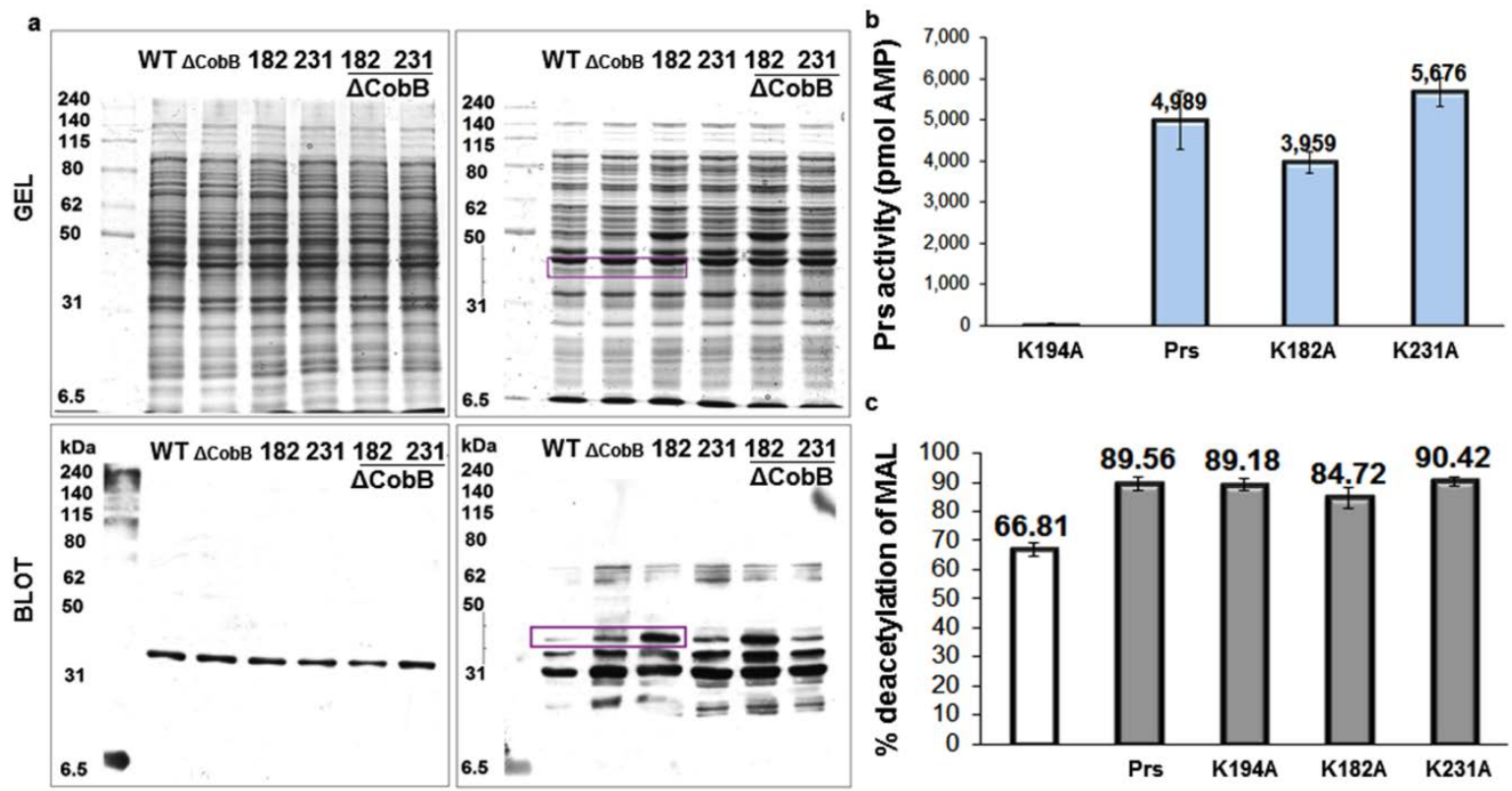

997 
bioRxiv preprint doi: https:/doi.org/10.1101/2020.12.09.417477; this version posted December 9, 2020. The copyright holder for this preprint (which was not certified by peer review) is the author/funder, who has granted bioRxiv a license to display the preprint in perpetuity. It is made available under aCC-BY-NC-ND 4.0 International license.

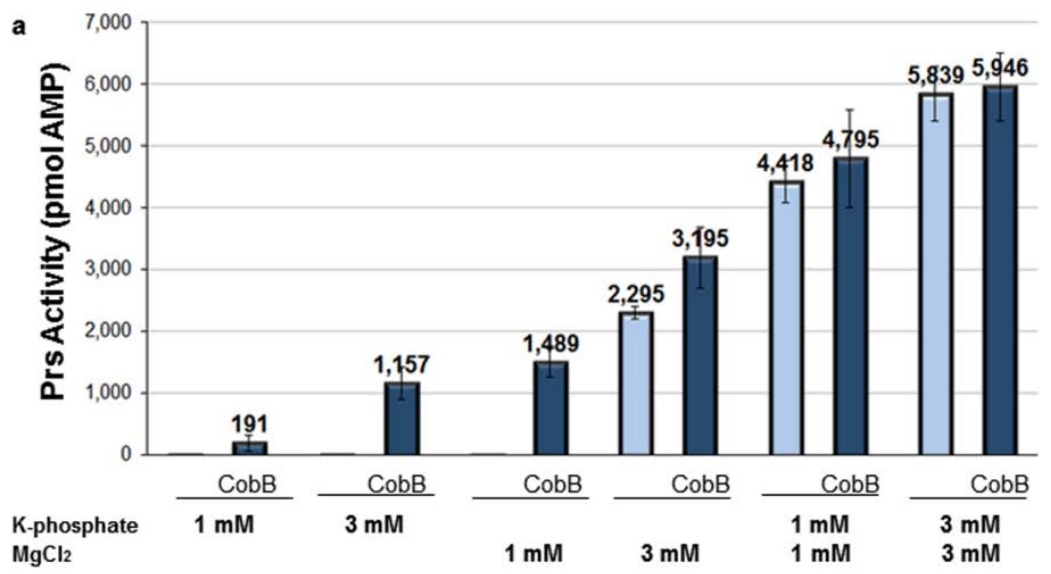

b

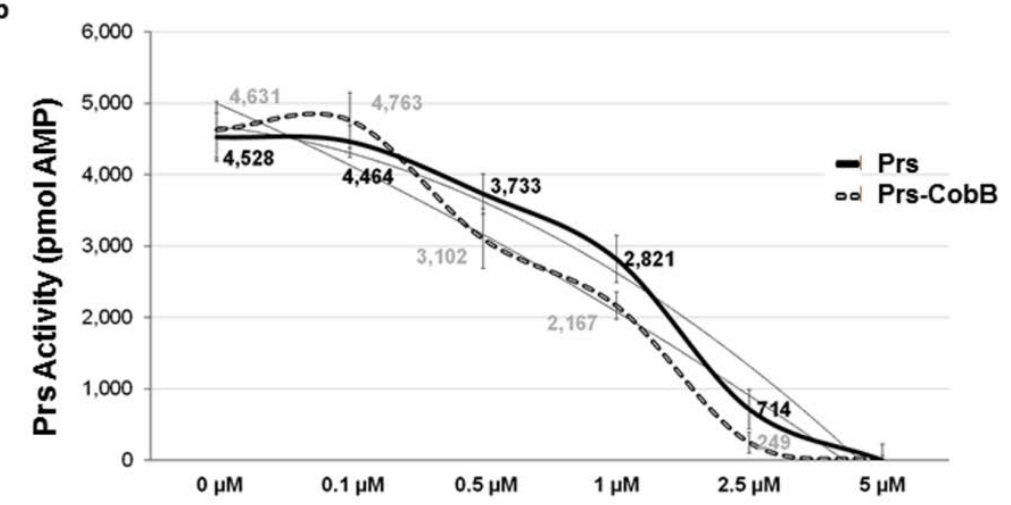

PRPP concentration 
bioRxiv preprint doi: https://doi.org/10.1101/2020.12.09.417477; this version posted December 9,2020 . The copyright holder for this preprint (which was not certified by peer review) is the author/funder, who has granted bioRxiv a license to display the preprint in perpetuity. It is made available under aCC-BY-NC-ND 4.0 International license.

1033

1034

1035

1036

1037

1038

1039

1040

1041

1042
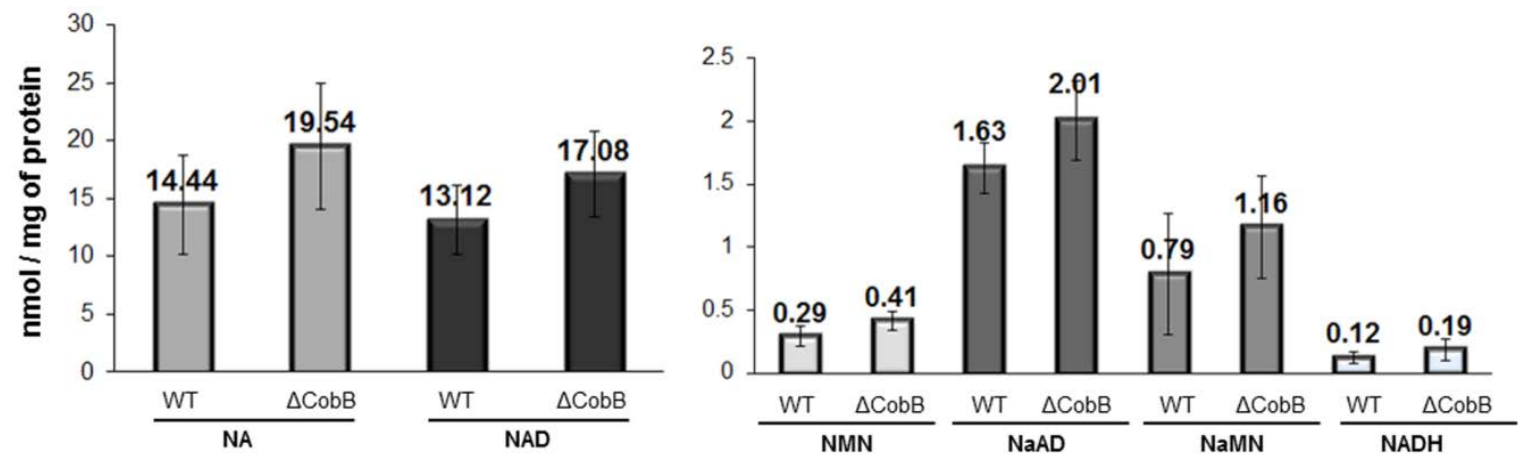

1043

1044

1045

1046

1047

1048

1049

1050

Fig. 6

1051

1052

1053 
bioRxiv preprint doi: $\mathrm{https}$ //doi.org/10.1101/2020.12.09.417477; this version posted December 9, 2020. The copyright holder for this preprint (which was not certified by peer review) is the author/funder, who has granted bioRxiv a license to display the preprint in perpetuity. It is made available under aCC-BY-NC-ND 4.0 International license.

1066

1067

1068

1069

1070

1071

1072

1073

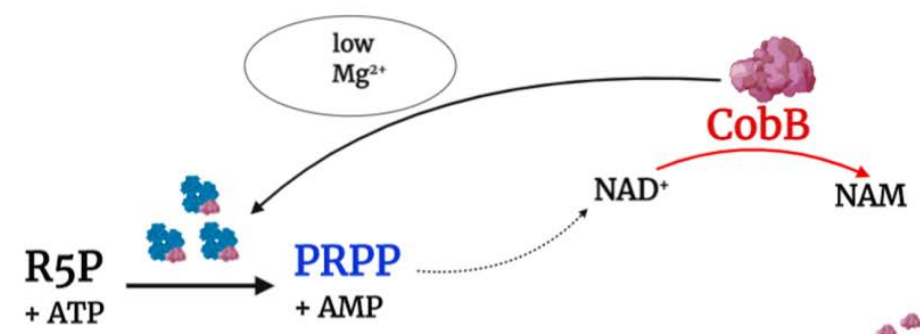

1074

1075

1076

1077

Fig. 7 